\title{
ENAMEL HIPOPLASIA PADA TENGKORAK MANUSIA PRASEJARAH DARI SITUS MELOLO, SUMBA, NUSA TENGGARA TIMUR (Hypoplasia Enamels in Human Skull Preparation from Melolo Site, Sumba, East Nusa Tenggara)
}

\author{
Desytri Ayu Herina, Toetik Koesbardiati \\ Departemen Antropologi, Fakultas Ilmu Sosial dan Ilmu Politik, \\ Universitas Airlangga Surabaya \\ e-mail: ayudesytri@gmail.com, toetik.koesbardiati@gmail.com
}

\section{INFO ARTIKEL}

Histori Artikel

Diterima: 8 Januari 2018 Direvisi: 2

Februari 2018 Disetujui: 4 Juni 2018

Keywords

Transition period,

EH, LEH,

Melolo Site

Kata Kunci

Masa transisi,

EH, LEH,

Situs Melolo
ABSTRACT

Cultural changes that occur during the Neolithic final transition to the beginning of the metal age are slowly providing consequences for the health problems of a population. Lifestyle changes that occurred during the transition resulted in the emergence of growth stress that must be faced by the population living in transition. Causes of developmental stress are unequal living conditions, nutritional stress, illness, dietary changes, and increased population density. Stress of growth period experienced by individuals can be recorded on bones and teeth as a pathology. Therefore, bones and teeth are part of the body that has plastic and dynamic characteristic. The pathology that can be recorded on the teeth as an indicator of stress is Enamel Hipoplasia (EH). The purpose of this study is to describe the emergence of $E H$ on the remaining order of human prehistori from Melolo site. The emergence of EH is identified macroscopically and uses photography methods with Alternative Light Source UV light tehnologi for documentation. EH on the remaining human skeletal order of Melolo has a pattern of horizontal or horizontal grooves called Linier Enamel Hipoplasia (LEH). EH with the LEH pattern is owned by 3 individuals from Melolo as a response from the development of transitional life from the late Neolithic era to the beginning of the metal age with the pattern of agriculture.

ABSTRAK

Perubahan budaya yang terjadi pada masa transisi akhir neolitik menuju awal zaman logam secara perlahan memberikan konsekwensi terhadap munculnya masalah kesehatan suatu populasi. Perubahan gaya hidup yang terjadi pada masa transisi mengakibatkan munculnya stres masa pertumbuhan yang harus dihadapi oleh populasi yang hidup pada masa itu. Penyebab munculnya stres masa pertumbuhan adalah ketidakseimbangan kondisi lingkungan tempat tinggal, tekanan gizi, kemunculan penyakit, perubahan pola diet, dan peningkatan jumlah kepadatan populasi. Stres masa pertumbuhan yang dialami oleh individu dapat terekam pada tulang dan gigi sebagai suatu patologi karena tulang dan gigi merupakan bagian tubuh yang plastis dan dinamis. Patologi yang dapat terekam pada gigi sebagai indikator terjadinya stres adalah Enamel Hipoplasia (EH). Penelitian ini bertujuan mendeskripsikan kemunculan EH pada sisa rangka manusia prehistori dari situs Melolo. Kemunculan EH diidentifikasi secara makroskopis menggunakan metode fotografi dengan tehnik Alternative Light Source sinar UV untuk dokumentasi. EH pada sisa rangka manusia prehistori dari Melolo berjenis lekuk mendatar atau horizontal yang disebut Linier Enamel Hipoplasia (LEH). EH berjenis LEH yang ditemukan pada tiga individu dari Melolo timbul sebagai respon terhadap perkembangan kehidupan pada masa transisi dari zaman akhir neolitik menuju awal zaman logam yang bercorak agrikultur. 


\section{PENDAHULUAN}

Paleopatologi adalah studi yang digunakan untuk dapat memahami penyebab, frekwensi, dan sifat penyakit pada populasi masa prehistori. Studi mengenai paleopatologi digunakan sebagai tolok ukur kesehatan sebuah populasi pada masa prasejarah. Paleopatologi dapat mempelajari langsung sebuah penyakit pada masa lampau melalui temuan sisa rangka manusia masa prehistori, artefak, dan catatan medis yang masih ada. Patologi pada temuan sisa rangka manusia umumnya ditemukan pada tengkorak dan gigi. Patologi yang ditemukan pada tengkorak di antaranya adalah porotik hiperostosis dan cibra orbitalia, sedangkan patologi yang umumnya ditemukan pada gigi adalah karies, atrisi gigi, periodontitis, antemorthem toothloss, dan enamel hipoplasia.

Enamel hipoplasia adalah salah satu jenis paleopatologi yang terdapat pada gigi yang dapat menjadi indikator stres nonspesifik, seperti kekurangan nutrisi dan munculnya penyakit, sehingga dapat digunakan untuk melihat kondisi kesehatan dan kesejahteraan populasi masa prehistori (Kinaston, 2010). Enamel hipoplasia adalah patologi yang terbentuk pada gigi akibat terdapatnya gangguan lingkungan yang diakibatkan oleh stres pada masa pembentukan gigi saat usia pertumbuhan. Definisi enamel hipoplasia secara medis dipahami sebagai kelainan pada struktur enamel gigi yang terjadi akibat adanya gangguan pada ameloblast pada tahap amelogenesis sehingga pembentukan struktur enamel tidak sempurna (Goodman, 1980; Hilson, 1999; Indriati, 2000). Ketidaksempurnaan yang terbentuk pada enamel ini bersifat tetap atau permanen dan dapat terjadi pada gigi sulung maupun gigi permanen. Hal ini disebabkan oleh beberapa faktor, seperti faktor stress metabolic, genetik, tekanan lingkungan, dan juga trauma (Rose, 1985).

Kemunculan enamel hipoplasia menunjukan adanya kerentanan kesehatan pada masa tumbuh kembang anak. Pertumbuhan dan perkembangan adalah suatu proses yang bergantung pada keadaan homeostatis tubuh dan sistem imun yang dimiliki oleh seorang individu. Untuk dapat mencapai keadaan tubuh yang homeostatis dan sistem imun yang kuat, individu harus memiliki asupan nutrisi dan gizi yang cukup dan seimbang. Pada masa tumbuh kembang, anak membutuhkan lebih banyak nutrisi dan gizi agar kebutuhan tubuh dalam proses pembentukan di masa tumbuh kembang ini dapat tercukupi. Kekurangan asupan gizi dan nutrisi yang dialami anak-anak dapat disebabkan oleh banyak faktor, baik lingkungan maupun budaya, di antaranya daerah dataran tinggi yang mendorong mereka lebih banyak mengkonsumsi makanan yang banyak mengandung 
karbohidrat saja, masa penyapihan yang pada masa transisi agrikultur sebagai akibat dilakukan oleh orang tua kepada anak- terjadinya stres nutrisi pada masa tersebut. Di anaknya, kondisi ekonomi yang rendah, dan Indonesia terdapat beberapa situs tempat juga adanya suatu penyakit. Jika anak-anak ditemukannya sisa rangka manusia yang mengalami kekurangan nutrisi dengan menunjukan ciri-ciri hidup pada masa transisi prevalensi waktu yang lama, hal tersebut agrikultur, salah satunya adalah situs Melolo. akan memengaruhi pembentukan enamel Situs Melolo adalah situs arkeologi yang pada gigi dan pada gilirannya akan kaya akan temuan sisa rangka manusia dan menyebabkan terbentuknya enamel hipoplasia.

Populasi yang teridentifikasi mengalami enamel hipoplasia dengan intensitas tinggi adalah populasi yang hidup pada masa transisi dari masa berburu ke masa agrikultur. Pada tahap perkembangan budaya agrikultur yang ditandai oleh kemampuan domestifikasi hewan dan tumbuhan, manusia mulai mengembangkan kemampuannya dalam bidang teknologi pengolahan pangan. Pada masa agrikultur ini manusia mulai hidup menetap (sedenter) dan lebih memilih untuk bercocok tanam daripada berburu hewan. Perkembangan budaya agrikultur merupakan awal munculnya permasalahan nutrisi yang dialami populasi pada masa ini. Pada masa agrikultur ini makanan utama yang dikonsumsi adalah kacang-kacangan dan umbi-umbian yang memiliki kadar karbohidrat tinggi. Tampak bahwa konsumsi karbohidrat manusia pada masa ini naik berkali-kali lipat, sedangkan konsumsi protein manusia sangat kurang.

Enamel hipoplasia umumnya ditemukan pada temuan sisa rangka manusia yang hidup

\section{METODE}

Penelitian ini bersifat kualitatif dengan menggunakan metode analisis deskriptif. Penelitian kualitatif adalah metode penelitian yang digunakan untuk meneliti objek ilmiah, sedangkan analisis deskriptif adalah penjabaran data berdasarkan realitas yang terlihat. Dari delapan belas individu rangka manusia prehistori dari Melolo yang menjadi koleksi temuan Museum Etnografi, penulis mengambil sebelas individu sampel sebagai subjek penelitian. Sebelas individu ini dipilih karena tujuh individu yang lain tidak terdapat bagian atau fragmen gigi-geligi, sementara tujuan utama penelitian ini adalah mendeskripsikan ada tidaknya enamel hipoplasia dan bagaimana pola enamel hipoplasia yang terdapat pada gigi-geligi tengkorak manusia prehistori dari Melolo.

Penelitian ini dilakukan di laboratorium Museum Etnografi dan Pusat Kajian Kematian, Fakultas Ilmu Sosial dan Ilmu 
Politik, Universitas Airlangga, Surabaya. memaparkan sinar UV pada objek foto Dalam penelitian ini, peneliti menggunakan sehingga objek foto akan bereaksi terhadap metode makroskopis, yaitu melihat dan radiasi sinar UV tersebut. Pada tahap akhir, mengidentifikasi bagian gigi-geligi rangka kamera DSLR yang telah ditetapkan prehistori dari Melolo. Ada tidaknya enamel pengaturannya akan menangkap reaksi objek hipoplasia pada rangka prehistori dari foto tersebut.

Melolo ini dapat dilihat secara visual dari permukaan enamel. Hal ini berdasarkan penjelasan Ortner (2003) bahwa kemunculan patologi pada sisa rangka manusia dapat terekspresi dari keadaan abnormalitasnya (terkait dengan formasi, destruksi, densitas, ukuran, dan bentuk tulang) yang berkaitan dengan fungsi fisiologis dan faktor penyebab kemunculanya. Selain dengan metode makroskopis, peneliti juga menggunakan metode Walker (2005). Dalam metode ini peneliti menggunakan ujung jari kelingking untuk meraba permukaan enamel pada gigi agar dapat merasakan kehadiran lekuk atau lesi sebagai indikasi terdapatnya enamel hipoplasia pada gigi.

Apabila setelah dilihat secara visual dan diraba dengan jari kelingking tengkorak prehistori dari Melolo teridentifikasi mengalami enamel hipoplasia, peneliti mendokumentasikannya dengan metode fotografi ALS (Alternative Light Source) sinar UV. Metode fotografi tehnik ALS sinar UV dianggap jauh lebih mampu memperlihatkan abnormalitas pada tulang dan gigi sebagai tanda terdapatnya patologi pada sisa rangka manusia. Metode fotografi tehnik ALS sinar UV dilakukan dengan

\section{TEMUAN DATA DAN PEMBAHASAN}

Enamel Hipoplasia pada Individu Melolo

Enamel hipoplasia adalah kerusakan enamel pada gigi yang disebabkan oleh gangguan ameloblast pada tahap amelogenesis. Amelogenesis sendiri terjadi dalam dua tahap, yaitu tahap sekresi matriks oleh ameloblast dan tahap maturasi. Aktivitas ameloblast yang terhambat pada tahap amelogenesis mengakibatkan pembentukan enamel yang tidak sempurna. Aktivitas ameloblast ini dapat terhambat karena faktor lingkungan yang menyebabkan stres fisiologis sehingga dapat mengurangi jumlah enamel yang seharusnya disekresikan. Sebagai akibatnya, muncul enamel hipoplasia sebagai defek gigi yang bersifat kwantitatif karena pada akhir fase sekresi enamel yang lebih tipis akan menjadi tempattempat defek enamel yang dapat berupa grooves, lekuk atau alur horizontal atau vertikal, dan defek tersebut dapat dihitung.

.Enamel hipoplasia merupakan indikator stres nonspesifik yang digunakan untuk mendeskripsikan tingkat kesehatan dan kesejahteraan populasi masa kuno. Patologi 
enamel hipoplasia yang terdapat pada manusia menandakan terjadinya malnutrisi atau gangguan tumbuh kembang pada masa pertumbuhan.

Enamel hipoplasia muncul secara bilateral pada bagian kanan, kiri, dan permukaan mahkota gigi. Enamel hipoplasia lebih banyak ditemukan pada bagian labial dan bucal. Ukuran lebar dan dalamnya lubang pada enamel gigi berhubungan langsung dengan tingkat keparahan stres yang dialami oleh individu. Satu gigi dapat mengalami satu atau lebih enamel hipoplasia. Enamel hipoplasia hanya akan menjangkiti gigi yang mahkotanya terbentuk pada masa stres berlangsung. Cacat pada enamel gigi akan terjadi pada enamel yang terbentuk pada masa interval waktu ketika faktor-faktor stres telah aktif memengaruhi pembentukan enamel. Tahap amelogenesis pada pembentukan gigi sulung terjadi selama masa kandungan (intrauterine), sedangkan tahap amelogenesis pada gigi permanen terjadi sejak individu lahir sampai usia 6 - 7 tahun atau sampai usia 13 tahun untuk molar.

Gigi yang paling rentan mengalami enamel hipoplasia adalah gigi yang pertumbuhan enamelnya terjadi pada usia 23 tahun. Incisivus dan canine dianggap sebagai gigi yang paling baik untuk menggambarkan enamel hipoplasia karena dianggap sebagai gigi yang paling dipengaruhi oleh stres fisiologis yang dialami oleh individu. Pembentukan enamel hipoplasia terjadi pada saat anak-anak dalam masa penyapihan. Pada masa penyapihan ini kondisi tubuh anak lebih rentan terkena infeksi bakteri atau parasit yang menyebabkan terhambatnya pencernaan nutrisi yang dibutuhkan oleh tubuh sehingga memicu munculnya enamel hipoplasia.

Enamel hipoplasia juga banyak dikaitkan dengan status ekonomi, infeksi penyakit, malnutrisi, dan kelahiran premature. Namun demikian, faktor utama yang mempengaruhi pembentukan enamel hipoplasia dapat dikategorikan dalam tiga kategori utama, yaitu malnutrisi, trauma, dan infeksi penyakit. Kemunculan enamel hipoplasia sebagai patologi juga tidak dapat dipisahkan dari faktor lingkungan. Tingkat stres yang dialami oleh individu dan faktor genetik yang dimilikinya adalah hal yang mempengaruhi bagaimana pembentukan jenis enamel hipoplasia pada individu tersebut. Setiap individu memiliki kemampuan tersendiri dalam merespon stres yang dihadapi. Faktor genetik merupakan salah satu faktor yang berpengaruh besar terhadap kemampuan setiap individu dalam merespon stres yang dihadapi. Dengan demikian, meskipun dua individu menghadapi stres yang sama, dampak stres yang dialami dua individu tersebut belum tentu sama. Enamel hipoplasia merupakan salah satu bentuk respon tubuh seorang individu manusia dalam menghadapi stres fisiologis. 


\begin{tabular}{|c|c|c|c|c|}
\hline $\begin{array}{c}\text { Kode } \\
\text { Temuan }\end{array}$ & Sisa Rangka Individu & $\begin{array}{c}\text { Jenis } \\
\text { Kelamin* }\end{array}$ & Umur* & EH \\
\hline \multirow{2}{*}{ Urne 1} & $\begin{array}{c}\text { Maxilla } \\
\text { (fragmen maxilla kiri) }\end{array}$ & \multirow{2}{*}{$\begin{array}{l}\text { Tidak dapat } \\
\text { ditentukan }\end{array}$} & \multirow{2}{*}{$6-8$ th } & - \\
\hline & $\begin{array}{c}\text { Mandibula } \\
\text { (bagian ramus kiri patah) }\end{array}$ & & & - \\
\hline \multirow{3}{*}{ Urne 2} & $\begin{array}{c}\text { Maxilla } \\
\text { (gigi tersisa I1, P1, P2, M1, } \\
\text { M2, M3 sisi kanan dan P2, } \\
\text { M1, M2, M3 sisi kiri) }\end{array}$ & \multirow{2}{*}{ Perempuan } & \multirow{2}{*}{$25-35$ th } & $\sqrt{ }$ \\
\hline & $\begin{array}{c}\text { Mandibula } \\
\text { (gigi tersisa PM1, PM2, M2 } \\
\text { sisi kiri dan C, PM1, M1, } \\
\text { M2, M3 sisi kanan) }\end{array}$ & & & - \\
\hline & $\begin{array}{c}\text { Mandibula } \\
\text { (fragmen ramus mandibula } \\
\text { kanan bagian proc. } \\
\text { condylaris dan sebagian } \\
\text { incsura) }\end{array}$ & Perempuan & $17-25$ th & - \\
\hline Urne 3 & $\begin{array}{c}\text { Mandibula } \\
\text { (bagian angulus mandibula } \\
\text { kanan absen) }\end{array}$ & Laki-laki & $25-35$ th & $\sqrt{ }$ \\
\hline Urne 5 & $\begin{array}{c}\text { Mandibula } \\
\text { (bag. ramus kanan, ujung } \\
\text { proc. coronoideus dan proc. } \\
\text { condylaris absen) }\end{array}$ & Perempuan & $<40$ th & - \\
\hline Urne 8 & $\begin{array}{c}\text { Mandibula } \\
\text { (bag. ramus kanan dan proc. } \\
\text { condylaris kiri absen) }\end{array}$ & Perempuan & $25-35$ th & - \\
\hline \multirow{3}{*}{ Urne E } & $\begin{array}{l}\text { Fragmen Maxilla } 1 \\
\text { (gigi tersisa } \mathrm{C}, \mathrm{P} 1, \mathrm{P} 2, \mathrm{M} 1 \text {, } \\
\mathrm{M} 2 \text { maxilla kiri dan } \mathrm{P} 2 \\
\text { maxilla kanan) }\end{array}$ & Laki-laki & $20-25$ th & $\sqrt{ }$ \\
\hline & $\begin{array}{l}\text { Fragmen Mandibula } \\
\text { (proc. condylaris dan proc. } \\
\text { coronoideus absen pada } \\
\text { bagian ramus) }\end{array}$ & Perempuan & $25-35$ th & - \\
\hline & $\begin{array}{c}\text { Fragmen Maxilla } 2 \\
\text { (gigi tersisa M1 dan M2) }\end{array}$ & Perempuan & $20-25$ th & - \\
\hline \multirow[b]{2}{*}{ Urne $\mathbf{G}$} & $\begin{array}{l}\text { Fragmen Mandibula } 1 \\
\text { (gigi tersisa M3, M2, M1) }\end{array}$ & Perempuan & $20-25$ th & - \\
\hline & $\begin{array}{c}\text { Fragmen Mandibula } 2 \\
\text { (fragmen mandibula sebelah } \\
\text { kiri) }\end{array}$ & Perempuan & $15-17$ th & - \\
\hline $\begin{array}{r}\text { Berdasa } \\
\text { terdapat tig }\end{array}$ & $\begin{array}{l}\text { tabel hasil pengamatan, } \\
\text { dividu yang teridentifikasi }\end{array}$ & $\begin{array}{l}\text { isa rangka } \\
\text { Melolo, Sumb } \\
\text { Urne 3, dan U. }\end{array}$ & $\begin{array}{l}\text { usia preh } \\
\text { TT, yaitu }\end{array}$ & \\
\hline
\end{tabular}


Pola EH pada Individu Melolo (Linier Enamel Hipoplasia/LEH)

Enamel hipoplasia dapat diklasifikasikan ke dalam enam jenis, yaitu 1) kekeruhan enamel berwarna kuning (enamel opacities coloured white), 2) kekeruhan enamel berwarna kuning atau coklat (enamel opacities coloured yellow or brown), 3) lekuk berbentuk garis mendatar (horizontal grooves) atau linier enamel hipoplasia (LEH), 4) lekuk berbentuk garis tegak lurus (vertical grooves), 5) pits atau lubang pada enamel (enamel pitting), 6) dan tidak terdapat enamel sama sekali (enamel missing) (Scultz, et al., 1998).

Linier enamel hipoplasia merupakan salah satu jenis enamel hipoplasia yang paling banyak ditemukan kasusnya pada gigigeligi populasi manusia prehistori. Linier enamel hipoplasia (LEH) dianggap sebagai sebuah indikator stres nonspesifik sejak masa kandungan hingga dewasa (Goodman \& Armelagos, 1989; Mays, 2010). Incisivus dan canine adalah gigi yang paling rentan mengalami LEH, sedangkan molar adalah gigi yang paling jarang memiliki LEH. LEH merupakan dampak dari terjadinya gangguan pada tahap amelogenesis sehingga dapat memunculkan sebuah lekukan yang berbentuk garis horizontal dan biasanya sedikit mengalami perubahan warna pada mahkota gigi (Hilson, 1996; Whright, 1997b).

Tingkat keparahan linier enamel hipoplasia dapat dilihat dengan diagram evaluasi enamel hipoplasia yang dibuat oleh Brothwell (1971). Brothwell (1971) membuat diagram evaluasi tingkat keparahan linier enamel hipoplasia dengan skala nilai nol sampai dengan tiga. Nilai nol menunjukkan gigi tidak terindikasi linier enamel hipoplasia, nilai satu menunjukkan gigi terindikasi linier enamel hipoplasia ringan, nilai dua menunjukkan gigi terindikasi linier enamel hipoplasia sedang, dan nilai tiga menunjukkan gigi terindikasi linier enamel hipoplasia parah.

Dari sebelas rangka individu manusia prehistori dari Melolo, Sumba, Nusa Tenggara Timur, terdapat tiga individu yang teridentifikasi memiliki enamel hipoplasia berjenis lekuk berbentuk garis mendatar (horizontal grooves) yang disebut linier enamel hipolpasia (LEH).

\section{- Individu Melolo Urne 2}

\begin{tabular}{|c|c|c|c|c|c|c|c|c|c|c|c|c|c|c|c|}
\hline \multicolumn{16}{|c|}{ Skeletal Material: Maxilla } \\
\hline \multicolumn{16}{|c|}{ Skeleton Number: Urne 2} \\
\hline \multicolumn{16}{|c|}{ Date: $29 / 04 / 2018$} \\
\hline M3 & M2 & M1 & PM2 & PM1 & $\mathrm{C}$ & $\mathrm{I} 2$ & I1 & I1 & $\mathrm{I} 2$ & $\mathrm{C}$ & PM1 & PM2 & M1 & M2 & M3 \\
\hline 0 & 0 & 0 & 0 & - & - & - & - & 1 & - & - & 0 & 0 & 0 & 0 & 0 \\
\hline
\end{tabular}




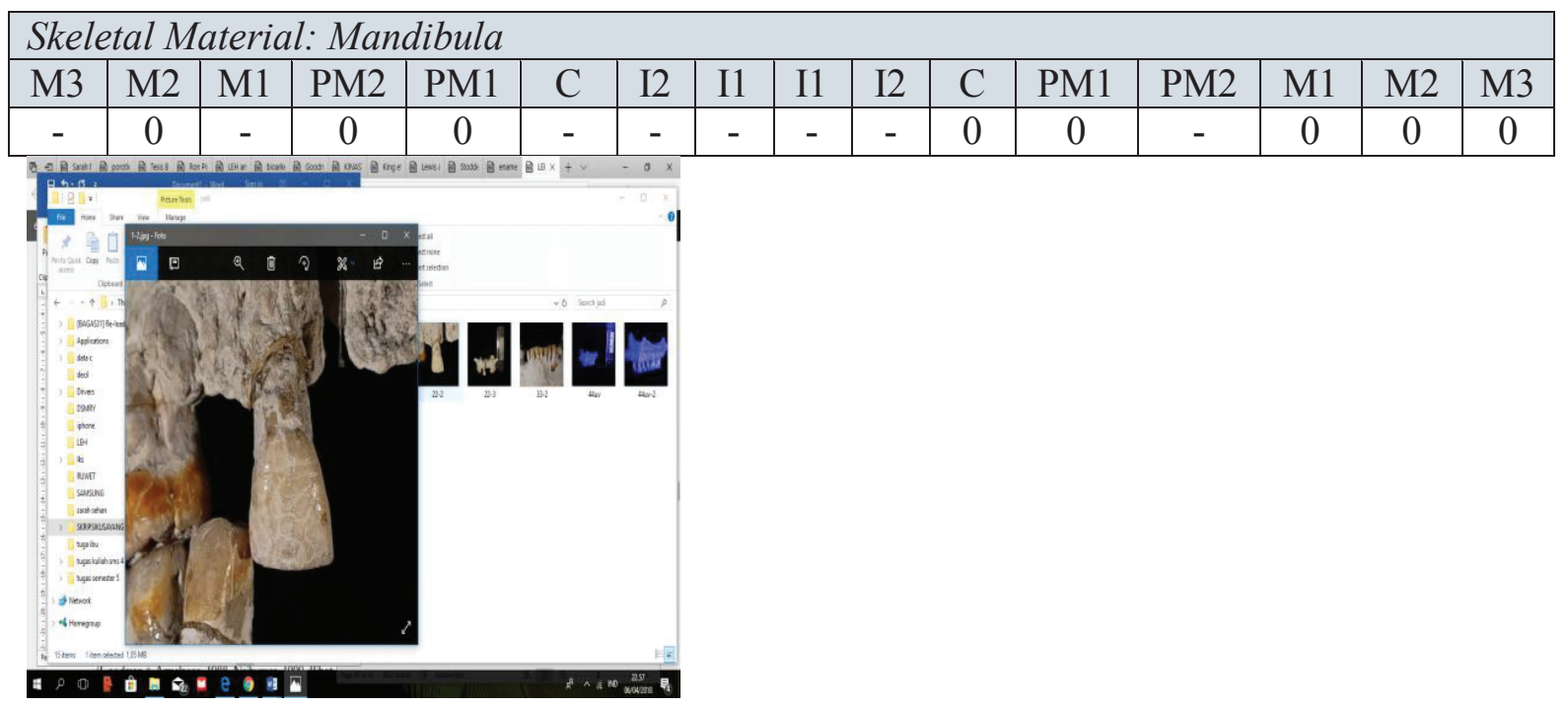

LEH yang hanya ditemukan pada satu kemungkinan penyebab munculnya LEH gigi pada individu Melolo Urne 2 tidak pada individu Melolo Urne 2. Kemungkinan cukup untuk dapat mendeskripsikan dan pertama adalah trauma, misalnya trauma membuktikan bahwa penyebab munculnya akibat proses melahirkan yang lama. LEH pada individu tersebut sebagai akibat Kemungkinan ini mengandung kebenaran sebuah trauma. Ketiadaan incisivus dan jika pada incisivus dan canine yang absen canine pada individu Melolo Urne 2 menjadi (tidak ada) memang tidak terdapat LEH. kendala dalam melakukan analisis terhadap Kemungkinan kedua adalah stres masa penyebab munculnya LEH pada individu pertumbuhan yang dapat diakibatkan oleh tersebut. Incisivus dan canine adalah gigi penyakit, tekanan gizi dengan durasi yang yang paling baik untuk mendeskripsikan cukup lama, atau tidak tercukupinya nutrisi stres yang dialami oleh individu selama pada saat masa kehamilan. Kemungkinan ini hidupnya karena insicivus dan canine adalah mengandung kebenaran jika pada incivus dan gigi yang paling rentan terhadap LEH. canine yang absen tersebut sebenarnya Berdasarkan hal tersebut terdapat dua terdapat LEH.

- Individu Melolo Urne 3

Skeletal Material: Mandibula
Skeleton Number: Urne 3
\begin{tabular}{|c|l|l|l|l|l|l|l|l|l|l|l|l|l|l|l|l|}
\hline Date: $29 / 04 / 2018$ \\
\hline M3 & M2 & M1 & PM2 & PM1 & C & I2 & I1 & I1 & I2 & C & PM1 & PM2 & M1 & M2 & M3 \\
\hline- & 0 & - & - & - & 0 & 0 & 0 & 0 & 1 & 0 & 0 & 0 & - & - & 0 \\
\hline
\end{tabular}




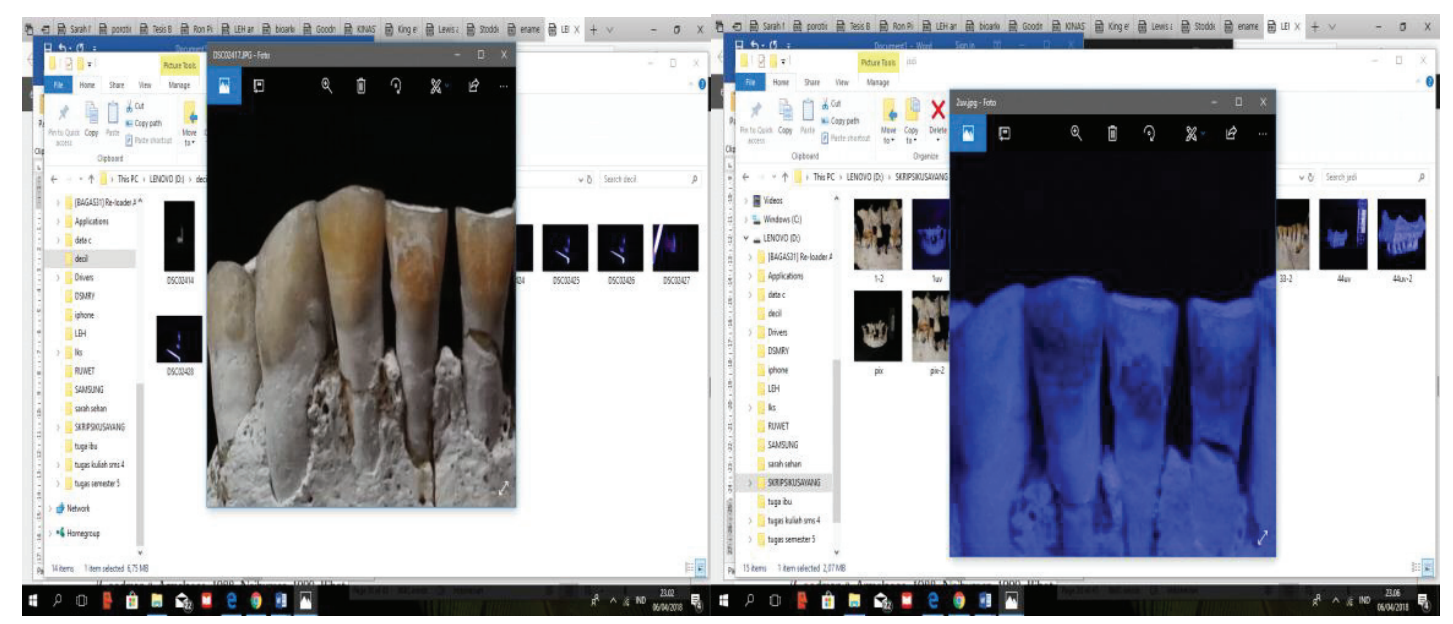

Berbeda halnya dengan individu Urne 2, pada mandibula Urne 3 tidak teridentifikasi meskipun individu Urne 3 hanya memiliki memiliki LEH. Canine dan incisivus adalah satu gigi yang teridentifikasi memiliki LEH, gigi yang paling rentan mengalami LEH penyebab munculnya LEH pada individu sehingga canine dan incisivus adalah gigi Urne 3 ini kemungkinan besar sebagai akibat yang paling baik untuk mendeskripsikan trauma penyakit tertentu atau trauma pada stres yang dialami oleh individu pada masa proses kelahiran. Hal tersebut dapat lampau.

dipastikan karena insicivus dan canine lain

- Individu Melolo Urne E

\begin{tabular}{|c|c|c|c|c|c|c|c|c|c|c|c|c|c|c|c|c|}
\hline \multicolumn{17}{|c|}{ Skeletal Material: Maxilla } \\
\hline \multicolumn{17}{|c|}{ Skeleton Number: Urne E } \\
\hline \multicolumn{17}{|c|}{ Date: $29 / 04 / 2018$} \\
\hline M3 & M2 & M1 & PM2 & PM1 & ( & & & & I1 & $\mathrm{I} 2$ & $\mathrm{C}$ & PM1 & PM2 & M1 & M2 & M3 \\
\hline- & 1 & 0 & 1 & 1 & 1 & ( & & & - & - & - & - & 1 & - & - & - \\
\hline
\end{tabular}



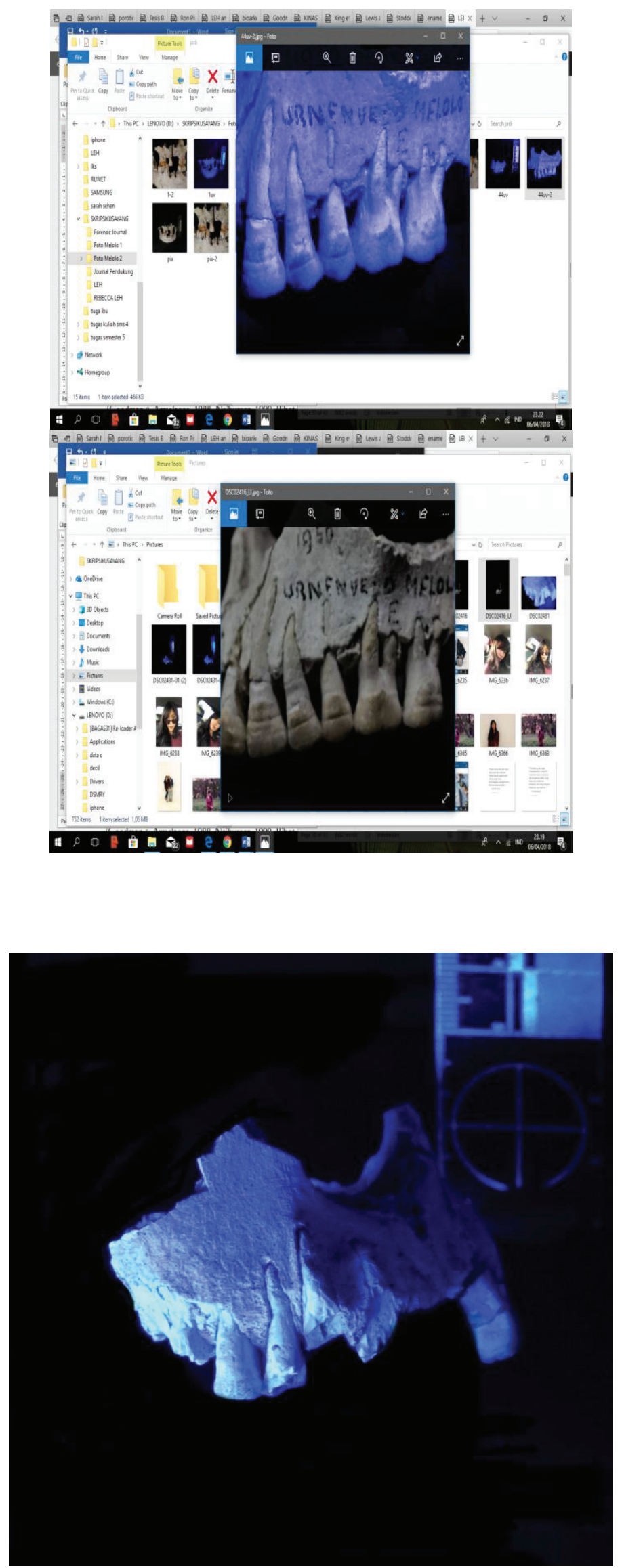
Bedasarkan tabel dapat diketahui bahwa terdapat lima gigi yang teridentifikasi memiliki LEH, yaitu M2 kiri, PM2 kiri, PM1 kiri, C kiri, dan PM2 kanan. LEH pada setiap gigi berpola lesi berbentuk lekuk horisontal atau horizontal grooves. Karena dapat dilihat secara kasat mata, tingkat kedalaman horizontal grooves pada setiap gigi masuk dalam tahapan sedang atau nilai 2 berdasarkan diagram evaluasi LEH Brothwell (1971).

Di C kiri dan PM1 kiri juga terdapat lebih dari satu LEH. Keadaan seperti ini menandakan bahwa individu Melolo Urne E memiliki LEH yang disebabkan stress masa pertumbuhan yang kronik sehingga merusak sistem metabolisme pada tubuh dan menjadi sebuah tekanan gizi yang memengaruhi pembentukan enamel. Tingkat keparahan stres nutrisi yang dialami oleh material Melolo Urne E melebihi tingkat keparahan stress yang dialami oleh material Melolo Urne 2 dan Urne 3 sehingga dapat terekam jelas pada gigi-geligi material Melolo Urne E. Sesuai pendapat Danforth (1999), jika terdapat lebih dari satu gigi yang memiliki LEH, munculnya LEH pada individu tersebut disebabkan oleh stres masa pertumbuhan sebagai akibat tekanan nutrisi dengan durasi waktu yang cukup lama, tekanan lingkungan, timbulnya penyakit, atau genetik.
Penyebab Munculnya EH pada Sisa

Rangka Manusia Prehistori Melolo

Material Melolo adalah populasi manusia kuno yang mempunyai fenotip Austramelanesoid yang berunsur Mongoloid. Fenotipe Australomelanesoid dan Mongloid muncul sebagai akibat dari gelombang migrasi yang dilakukan secara intensif oleh ras Mongoloid yang kemudian mendesak dan berbaur dengan populasi asli, yaitu Australomelanesoid.

Populasi situs Melolo tinggal di sepanjang pesisir pantai Sumba Timur, Flores, Nusa Tenggara Timur. Kawasan di sekitar situs Melolo beriklim tropis dengan musim kemarau yang lebih panjang dan curah hujan sedikit. Topografi permukiman populasi Melolo berupa perbukitan kapur hasil sedimentasi batu apung dan aglomerat yang muncul akibat adanya aktivitas gunung berapi (Murti, 2011). Wilayah Sumba umumnya merupakan wilayah perbukitan, dataran rendah, pantai, dan lembah. Sistem pemukiman populasi Melolo berbentuk pola komunitas kecil di sepanjang tepi pantai. Kondisi ini terlihat jelas pada situs pemakaman Melolo yang padat, dan dari sana terindikasi bahwa populasi Melolo dahulu hidup di sepanjang tepi pantai dengan populasi yang cukup padat. Selama hidupnya, material Melolo menempati rumah yang beratap dan berlantai batu atau 
menempati sebuah gua yang berada dekat dengan tepi pantai (Nelson, 2000).

Populasi di situs Melolo merupakan populasi masa kuno yang hidup pada periode transisi dari akhir neolitik menuju ke permulaan zaman logam atau paleometalik, yakni sekitar 2000-3000 tahun yang lalu (Koesbardiati dan Suriyanto, 2007; Van Heekeren, 1972; 191-196). Periode zaman neolitik ditandai adanya alat batu yang sudah diproses halus (polished stone tools), pola kehidupan yang sudah menetap, kegiatan bercocok tanam, kegiatan domestikasi hewan, dan penggunaan gerabah (Shaw \& Jameson, 1999). Latar belakang kehidupan material Melolo dapat dilihat dari artefak yang ditemukan, terutama alat batu berukuran kecil (flakes), kapak batu, gerabah yang terbuat dari tanah liat yang dibakar, gerabah yang sudah dipoles halus dengan pola geometris dan wajah manusia, dan perhiasan yang terbuat dari cangkang kerang. Latar belakang kehidupan yang demikian merujuk pada ciri-ciri populasi yang hidup pada awal zaman logam (Heekeren, 1956).

\section{Kemunculan enamel hipoplasia} dipengaruhi oleh beberapa faktor, di antaranya keadaan geografis, pola diet, infeksi penyakit, genetik, stres sistemik, status ekonomi, dan trauma. Pada masa prehistori enamel hipoplasia termasuk ole patologi yang sering dijumpai dalam tumbuhan. Populasi pada masa bercocok persentase tinggi. Kemunculan enamel tanam ini mulai mengembangkan hipoplasia pada tiga individu Melolo kemampuannya dalam bidang teknologi

dialami oleh populasi Melolo. Populasi Melolo yang hidup pada masa transisi akhir neolitik menuju awal paleometalik mengalami perubahan pola hidup, dari pola hidup berpindah-pindah ke pola hidup menetap. Perubahan pola hidup yang disertai perubahan mata pencaharian, yaitu bercocok tanam dan domestikasi, mengakibatkan kepadatan populasi menjadi semakin meningkat. Kondisi ini mengakibatkan munculnya stres atau tekanan yang dialami individu, terutama anak-anak pada populasi Melolo. Peningkatan kepadatan penduduk berpengaruh pada penurunan tingkat kesejahteraan populasi. Selanjutnya, penurunan tingkat kesejahteraan populasi berakibat pada munculnya gangguan pertumbuhan, kekurangan vitamin A dan vitamin D, serta infeksi penyakit, seperti tuberkulosis dan sipilis (Goodman dan Armelagos, 1989).

Perubahan lain yang menyebabkan munculnya enamel hipoplasia pada material Melolo adalah perubahan pola diet yang dialami. Perubahan pola diet yang terjadi pada masa peralihan dari masa berburu menuju masa bercocok tanam sangat memengaruhi tekanan sistemik dalam tubuh. Perkembangan masa bercocok tanam ditandai oleh kemampuan domestikasi hewan dan

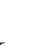

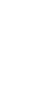

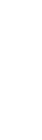


pengolahan pangan. Perkembangan yang terjadi pada masa bercocok tanam membawa dampak pada munculnya masalah nutrisi yang dihadapi oleh populasi. Masalah ini muncul akibat asupan utama yang dikonsumsi populasi berasal dari umbiumbian yang berkadar karbohidrat tinggi, sementara pada masa sebelumnya asupan utama yang dikonsumsi populasi bersumber dari makanan yang berprotein tinggi. Perubahan pola asupan nutrisi dari konsumsi yang mengutamakan protein (protein-based) ke konsumsi ysng mengutamakan karbohidrat (carbohydrate-based) memicu munculnya patologi pada populasi, di antaranya enamel hipoplasia (Cochran \& Harpending, 2009). Selain itu, perubahan pola asupan nutrisi seperti ini juga menyebabkan terjadinya tekanan nutrisi atau kekurangan gizi pada saat masa kehamilan (Koesbardiati, 2014).

\section{Hubungan Antara Umur Mati Individu dan Kemunculan EH}

Enamel hipoplasia berkaitan dengan stres masa pertumbuhan anak dan usia kematian yang relatif lebih rendah. Individu dengan cacat enamel yang terbentuk pada saat dalam kandungan atau pada masa pertumbuhan cenderung mengalami kematian pada usia remaja atau sebelum dewasa. Hipotesis tersebut dicetuskan oleh David JP Barker seorang ahli yang berasal dari
Universitas Southampton, Inggris. Barker telah menyatakan bahwa banyak sekali penyakit dewasa yang sesungguhnya disebabkan oleh gangguan masa pertumbuhan pada usia anak atau bahkan saat berada di dalam kandungan.

Barker juga menyebutkan bahwa setiap keadaan yang mengaggu masa pertumbuhan seorang individu, baik pada usia pertumbuhan maupun kandungan, akan berdampak negatif pada kesehatan individu tersebut pada masa dewasa. Sebagai contoh, seorang ibu yang mengalami gangguan psikologis ekstrim atau mengalami kekurangan asupan sehingga menderita kelaparan memiliki resiko tinggi terhadap kelahiran bayi dengan gangguan skizofrenia. Terdapat juga bukti bahwa perkembangan sistem kekebalan tubuh dipengaruhi oleh stressor kehidupan awal yang memiliki efek jangka panjang. Sebagai contoh, terdapat hubungan antara ibu yang memiliki gangguan atau infeksi pernafasan selama kehamilan dan resiko bayi lahir dengan gangguan penyakit asma (Goodman dan Armelagos, 1989).

Hubungan antara stres yang terjadi pada usia pertumbuhan dan kematian pada usia dini memiliki tiga mekanisme, yaitu: 1) terdapat pola diferensial yag berlaku seumur hidup yang diakibatkan oleh stres yang dialami. Artinya, setiap individu yang mengalami stres selama masa pertumbuhan dapat menyebabkan tubuh mereka lebih 
rentan terhadap munculnya enamel gambaran mengenai kedaan lingkungan dan hipoplasia sebagai patologi yang dapat tingkat kesejahteraan yang dimiliki oleh menyebabkan individu mati lebih awal populasi masa prehistori. Dari sebelas dibandingkan dengan individu lainnya yang individu Melolo yang diteliti, terdapat tiga tidak memiliki enamel hipoplasia. 2) individu yang teridentifikasi memiliki enamel Enamel hipoplasia pada individu dapat hipoplasia yang berjenis linier enamel menunjukan pola budaya dan perilaku hipoplasia (LEH). Jenis linier enamel terhadap stressor. Setiap individu dengan hipoplasia tersebut dapat dilihat melalui pola tingkatan keparahan enamel hipoplasia lesi pada gigi-geligi yang teridentifikasi, masing-masing dapat menggambarkan yaitu berbentuk lekuk horizontal atau tingkat stres masa pertumbuhan yang horizontal grooves.

dihadapi, dalam hal ini enamel hipoplasia Umur mati dipengaruhi oleh munculnya juga dapat menggambarkan kondisi linier enamel hipoplasia (LEH) pada lingkungan yang dapat menyebabkan individu. Linier enamel hipoplasia dengan munculnya stres pada individu tersebut. 3) nilai tingkat keparahan yang tinggi tentu saja Stres masa pertumbuhan yang akan mempengaruhi umur mati individu. Dua mengakibatkan munculnya enamel individu, yaitu Urne 2 dan Urne 3, yang hipoplasia dapat menurunkan sistem diperkirakan berumur mati sekitar 25-35 kekebalan tubuh individu. Sistem kekebalan tahun memiliki LEH dengan tingkat tubuh individu yang mengalami penurunan keparahan satu atau tahap ringan. Individu dapat mengakibatkan tubuh individu lebih Melolo Urne E yang diperkirakan berumur rentan terhadap serangan berbagai patogen mati sekitar 20-25 tahun memiliki nilai lain yang merugikan tubuh seperti berbagai tingkat keparahan LEH dua atau tahap macam penyakit (Goodman dan Armelagos, sedang. Tingkat keparahan LEH yang lebih 1989).

\section{PENUTUP}

Enamel hipoplasia merupakan patologi yang dapat digunakan sebagai indikator terjadinya stres nonspesifik pada populasi prehistori, seperti defisiensi nutrisi, infeksi penyakit, dan trauma. Oleh sebab itu, enamel hipoplasia dianggap dapat memberikan akan mengurangi umur mati individu sekitar lima sampai sepuluh tahun dibandingkan dengan tingkat keparahan LEH yang lebih rendah. Hal tersebut menunjukan bahwa kemunculan LEH dan tingkat keparahan LEH yang terdapat pada gigi-geligi mempengaruhi umur mati individu.

Kemunculan linier enamel hipoplasia pada sisa rangka manusia prehistori dari situs Melolo, Sumba, Nusa Tenggara Timur 
merupakan respon terhadap perkembangan kehidupan manusia dari periode transisi akhir per neolitik menuju awal zaman logam. Masa dan transisi ini berdampak pada terjadinya perlahan. Penurunan kualitas hidup manusia perubahan lingkungan, permasalahan tergambar dari stres fisiologis yang harus kesehatan, dan peningkatan jumlah populasi dialami oleh populasi manusia prehistori manusia. Pada periode neolitik ini juga Melolo. Stres fisiologis tersebut berkembang budaya agrikultur yang menyebabkan munculnya linier enamel memberikan banyak pengaruh, di antaranya hipoplasia sebagai penanda terjadinya perubahan pola diet pada populasi dengan ketidakseimbangan lingkungan dan asupan yang semula protein-based menjadi peningkatan kepadatan populasi. carbohydrate-based. 


\section{DAFTAR PUSTAKA}

Armelagos, George J.; Goodman, Alan H.; Harper, Kristin N.; Blakey, Michael L.;. 2009. Enamel Hypoplasia and Early Mortality: Bioarcheological Support for the Barker Hypothesis. Evolutionary Anthropology, Volume XVIII, pp. 261-271.

Cochran, G. dan Harpending, H. 2009. The 10,000 Year Explosion: How Civilization. s.1.:s.n.

Goodman, A. H. dan Armelagos, G. J. 1985. Factors affecting the distribution of enamel hypoplasias within the human permanent dentition. The Official Journal of The American Association of Physical Antrhopologist, pp. 479-493.

Goodman, A. H. dan Armelagos, G. J. 1989. Infant and Childhood Morbidity and Mortality Risk in Archaelogical Populations. World Acrhaeology, Volume 21, pp. 225-243.

Heekeren, H. R. V. 1956. The Urn Cemetery At Melolo, East Sumba. Bulletin of The Archaeological Service of the Republic of Indonesia.

Indriati, I. S. 2000. Penatalaksanaan Gigi Hipoplasia Email. Jurnal Kedokteran Gigi Universitas Indonesia, Volume 7, pp. 132-136.

Koesbardiati, T. 2014. Rekonstruksi Alam dan Kehidupan Berdasarkan Rangka. Surabaya: Airlangga University Press.

Koesbardiati, T. dan Suriyanto, R. A. 2007. Australomelanesoid in Indonesia: A swinginglike movent. Jurnal Anatomi Indonesia, II(1), pp. 23-28.

Mays, S. 2010. The Archaeology of Human Bones. London: Routledge: s.n.

Murti, D. B. 2011. Beberapa Patologi Pada Seri Tengkorak dan Gigi dari Situs Liang Bua, Lewoleba, dan Melolo: Suatu Tinjauan Bioarkeologis dan Rekomendasi Konservasinya. pp. 114-142.

Nelson, S. 2000. Encyclopedia of Prehistory Volume 3: East Asia and Oceania. New York: Yale University.

Pitsios, T. 2012. Frequency and Distribution of Enamel Hypoplasia in Acient Skulls From Different Eras and Areas in Greece. 5(2).

Putri, R. S. 2016. Deteksi Kelainan Cranium Manusia Dalam Lingkup Fotografi Forensik Dengan Sinar Inframerah, Ultraviolet, Dan Cahaya Normal Untuk Kepentingan Individualisasi. pp. 42-55.

Scultz, M. et al. 1998. Dental Antrhopology. New York: Departement Of Human Genetics and Anthropology.

Shaw, I. dan Jameson, R. 1999. A Dictionary of Archaeology. Oxford: Blackwell Publisher Ltd

Simalcsik, R. D., Simalcsik, A. \& Groza, V. M. 2013. Dental Enamel Hypoplasia. Investigations On The Bones Exhumed From The Medieval Necropole of Lozova (Republic of Moldova), XIVth-XVth Centuries.

Steckel, R. H., Larsen, C. S., Sciulli, P. W. \& Walker, P. I. 2005. Data Collection Codebook. The Global History of Health Project, p. 15.

Waldron, T. 2009. Paleopathology. Dalam: Paleopathology. London: Cambridge University Press.

Wetzel, M. J. K. 2007. Analysis of Enamel Hypoplasias in the Old Frankfort Cemetery: Comparisons Between Adult Male and Female and Juvenile Prevalence and Age at Onset Of Defects. pp. 87-102.

Whright, L. E. \& Chew, F. 1998. Porotic Hyperostosis and Paleoepidemiology: A Forensic Perspective on Anemia among the Ancient Maya. American Anthropologist, pp. 924-939 